Gontar, N.N., \& Galina, A.Y. (2022). Traceability as an element of the system of state control over the goods turnover. Actual Issues of Modern Science, 4(19), 19-28. Ostrava: Tuculart Edition.

Гонтарь, Н.Н., Галина, А.Ю. (2022). Прослеживаемость как элемент системы государственного контроля за оборотом товаров. Actual Issues of Modern Science, 4(19), 19-28. Ostrava: Tuculart Edition.

$$
\text { DOI: } 10.47451 / \text { jur2022-01-02 }
$$

The paper will be published in Crossref, Internet Archive, Google Scholar, Academic Resource Index ResearchBib, JGate, ISI, CiteFactor, ICI, eLibrary databases.

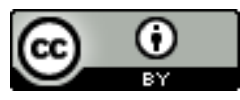

Nina N. Gontar, Associate Professor, Candidate of Sciences in Jurisprudence (PhD), Department of Public and Municipal Administration, Northwestern Institute of Management, Russian Academy of National Economy and Public Administration, Russian State University of Justice, St Petersburg, Russia.

Anastasia Y. Galina, Master's Student, Northwestern Institute of Management, Russian Academy of National Economy and Public Administration, St Petersburg, Russia.

\title{
Traceability as an element of the system of state control over the goods turnover
}

Abstract: The priority areas of the state's activities include ensuring the national security of the Russian Federation and controlling the turnover of illegal products. National security, including food security, is conditioned by many factors. One of them is the possibility of traceability of the goods movement at all stages of their turnover and control over the safety of such goods. Documentary traceability is not transparent. There is no possibility to track the goods movement in real-time. Also, paper accompanying documents are easily forged, which allows you to enter the market of illegal (counterfeit and falsified) products. The purpose of the study is to analyse the features of the Concept of creating and functioning in the Russian Federation of a system of labelling goods using identification and traceability of the movement of goods. Analytical, logical, and historical methods were used to achieve the purpose and solve the research tasks. In the study course, materials of state and international documents were used: federal laws, resolutions and orders of the Government of the Russian Federation, the National Marking System "Honest MARK". The authors conclude that the traceability development is extremely significant for the management of commodity flows, tax deductions, and product quality since despite the sufficiently debugged and digitized goods' labelling system on the Russian Federation territory and its compatibility with labelling control systems in other countries, there are still some elements of the system that allow bypassing it.

Keywords: traceability, turnover of goods, labeling of goods, consumer, federal law, decree of the Government of the Russian Federation.

Нина Николаевна Гонтарь, доцент, кандидат юридических наук, кафедра государственного и муниципального управления, Северо-Западный институт управления, Российская Академия народного хозяйства и государственной службы, Российский Государственный университет правосудия, Санкт-Петербург, Россия.

Анастасия Ю рьевна Галина, магистрант, Северо-Западный институт управления, Российская Академия народного хозяйства и государственной службы, Санкт-Петербург, Россия.

Прослеживаемость как элемент системы государственного контроля за оборотом товаров 
Аннотачия: В число приоритетных направлений деятельности государства входит обеспечение национальной безопасности Российской Федерации и контроль за оборотом нелегальной продукции. Национальная безопасность, в том числе продовольственная, обуслав ивается рядом факторов, одним из которых выступает возможность прослеживаемости Авижения товаров на всех этапах их оборота и контроль за безопасностью таких товаров. Аокументальная прослеживаемость не является прозрачной, отсутствует возможность в реальном времени отследить перемещение товара. Также бумажные сопроводительные документы мегко подлелываются, что позволяет проникать на рынок нелегальной (контрафактной и фальсифицированной) продукции. Целью исследования является анализ особенностей Концепции создания и функционирования в Российской Федерации системы маркировки товаров средствами идентификации и прослеживаемости Авижения товаров. Аля Аостижения цели и решения задач исследования применялись анаАитический, Аогический и исторический методы. В ходе исследования использовались материалы государственных и международных Аокументов: фелеральные законы, постановления и распоряжения Правительства Российской Фелерации, Национальная система маркировки «Честный ЗНАК». Авторы делают заключение, что развитие прослеживаемости явАяется крайне важным Аля управления товарными потоками, налоговыми отчислениями и качеством продукции, так как несмотря на Аостаточно отлаженную и оцифрованную систему маркировки товаров на территории Российской Федерации и её совместимость с системами контроля маркировки в иных странах, Ао сих пор существуют некоторые элементы системы, которые позволяют обходить её.

Ключевые слова: прослеживаемость, оборот товара, маркировка товара, потребитель, федеральный закон, постановление Правительства Российской Федерации.

\section{Introduction}

The priority areas of the state's activities include ensuring the national security of the Russian Federation and controlling the turnover of illegal products. National security, including food security, is conditioned by many factors. One of them is the possibility to trace the goods movement at all stages of their turnover and control over the safety of such goods (Decree of the President of the Russian Federation No. 683).

At this moment, in the Russian Federation, the traceability of the goods is implemented in documentary and digital form, depending on the group of goods. The introduction of mandatory labelling in Russia began in 2015 when it was decided to create a unified information system for monitoring goods. The creation of a new system and conducting experiments were entrusted to the Federal Tax Service of the Russian Federation. Later, the Center for the Development of Advanced Technologies (CRPT) became the national operator of the Honest MARK accounting system. According to the developed plan, the Honest MARK accounting system should cover all categories of goods by 2024 .

Documentary traceability is not transparent. There is no possibility to track the movement of goods in real-time. Also, paper accompanying documents are easily forged, which allows you to enter the market of illegal (counterfeit and falsified) products.

To date, traceability of the using digital technologies is the most effective element of the system of state control over the goods turnover.

The study subject is traceability as an element of the system of state control over the goods turnover. 
The study purpose is to analyse the features of the Concept of Creating and Functioning of Labelling Goods System Using Identification and Traceability of the Goods Movement in the Russian Federation.

Based on the study purpose, the following tasks were:

- give a general description of the marking system;

- $\quad$ analyse the Concept of Creating and Functioning of Labelling Goods System Using

Identification and Traceability of the Goods Movement in the Russian Federation;

- determine the preferential characteristics of goods labelling in the Russian Federation.

Analytical, logical, and historical methods were used to achieve the goal and solve the research tasks.

In the study course, materials of state and international documents were used: federal laws, resolutions and orders of the Government of the Russian Federation, the National Marking System "Honest MARK".

\section{General characteristics of the marking system}

Tracking tools using information and communication technologies include:

- identification;

- means of electronic identification (seals, tags, markers), which allow, based on machinereadable identifiers, to record, store or transmit data in electronic form;

- tracking tools that allow you to record changes in the parameters of the object (e.g., location);

- data registers, digital descriptions of objects;

- electronic documents (electronic accompanying documents, electronic reporting, declaration), transaction data (payment, customs operations) (Shklyaruk, 2019).

Various state information systems of traceability have been introduced and are functioning in the Russian Federation. As part of this study, we will consider the most ambitious - a system of digital labelling and traceability of goods. This system is one of the "trends" of the digitalization of the Russian economy.

The system of goods marking and traceability represents the interrelation of elements of information technology of organizational and regulatory nature, ensuring the achievement of purposes and tasks of traceability.

The elements of the marking and traceability system of goods are:

- $\quad$ state information system for labelling goods;

- interaction of government bodies, producers, subjects of the commodity distribution chain and consumers;

- regulatory legal framework in the field of labelling of goods;

- monitoring the turnover of goods subject to labelling.

\section{Concept of Creating and Functioning the Labelling Goods System Using Identification and Traceability of the Goods Movement in the Russian Federation}

In 2018, Russia approved the Concept of Creating and Functioning the Labelling Goods System Using Identification and Traceability of the Goods Movement in the Russian Federation 
(Order of the Government of the Russian Federation No. 2963-r). The concept was developed following the Agreement on Goods Labeling Using Identification in the Eurasian Economic Union (Agreement on Goods Labeling Using Identification in the Eurasian Economic Union; Agreement on the Goods Marking Using Identification in the Eurasian Economic Union) and the Strategy for Combating Illicit Trafficking in Industrial Products in the Russian Federation for the Period up to 2020 and the Planning Period up to 2025 (Order of the Government of the Russian Federation No. 2592-r). The concept defines the system purposes and tasks, its main parameters and requirements for it.

The stages of product turnover using the digital marking and traceability system are:

1. Application of a digital code by the manufacturer to the product. The labelling operator of CRPT LLC (Center for the Development of Advanced Technologies LLC) ensures that each product is assigned a unique code to be placed on the packaging of the goods by the manufacturer or importer.

2. Fixing the "path" of products in the distribution chain. The marking code cannot be lost or forged. It allows the control system to trace the reliable path of products at all stages of their turnover.

3. Scanning the product marking code in the store.

4. Sale of goods - withdrawal of the corresponding code from circulation. When selling at the checkout, the labelling system will not allow enterprises to sell counterfeit products.

5. The ability to view product information through the Honest Sign mobile application.

In Russia, the state information system for monitoring the goods turnover is subject to mandatory labelling using an identification (GIS MT) (Federal Law No. 381-FZ), as well as the federal state information system for monitoring the movement of medicines for medical use (GIS MDLP) (Federal Law No. 61-FZ; Order of the Government of the Russian Federation No. 899-r) are established and operate based on a public-private partnership agreement. In recent years, projects implemented through public-private partnerships to create digital economy infrastructure have become increasingly widespread.

In this case, the Ministry of Industry and Trade of the Russian Federation is the coordinator of the digital marking and traceability system. One of its functions in the framework of the labelling project is the definition of commodity groups that are subject to mandatory labelling, as well as regulatory regulation of related processes.

The operator of both GIS MT and FGIS MDLP is defined by CRPT LLC (Order of the Government of the Russian Federation No. 620-r; Order of the Government of the Russian Federation No. 2828-r). The creation and development of GIS MT and FGIS MDLP are provided at the expense of a private partner, an Operator, within the framework of a corresponding PPP project.

Before the entry into force of the requirements for mandatory labelling to a certain product group, an experiment, which provides for testing the mechanisms of functioning the traceability system of the turnover of this group, is realised. The experiment is voluntary and allows the participants of the turnover to prepare in advance for the entry into force of mandatory labelling requirements.

In part legally significant time mandatory labelling using identification and commitment to make information about all stages (without exception) supply chain in GIS MT and FGIS MDLP occur for: 
- dairy products (with June 1, 2021, for cheese and ice cream, with September 1, 2021, for products with a short shelf life up to 40 days, with December 1, 2021, for products with a long shelf life of more than 40 days);

- $\quad$ tobacco products, fur coats, footwear products, cameras, flashlights and flash lamps from July 1, 2020;

- $\quad$ perfumes and toilet water - from October 1, 2020;

- new pneumatic rubber tires and tires - from November 1, 2020;

- certain light industry goods - from January 1, 2021;

- medicines of the List of Vital and Essential Medicines for Medical Usage - from October 1, 2019;

- $\quad$ other medicines for medical use - from July 1, 2020.

Since 2022, the list of goods required for labelling has been supplemented with new items:

- bicycles and bicycle frames, packaged water (drinking and carbonated, with sugar, sweeteners and flavourings) - from March 1;

- beer and low-alcohol drinks, dietary supplements, antiseptics - from September 1;

- dairy products from suppliers-peasant farms - from December 1.

The Decree of the Government of the Russian Federation No 792-r of 28.04.2018 (ed. 05.10.2021) "On Approval of the List of Individual Goods Subjecting to Mandatory Labelling Using an Identification" establishes specific requirements for which goods are subject to labelling in 2022, the list of mandatory products contains not only the name and type of goods but also additional identification codes:

- $\quad$ code according to the All-Russian Product Classifier OK 034-2014, approved by

Rosstandart Order No. 14-st dated January 31, 2014;

- code for the Trade Nomenclature of the Eurasian Economic Union for Foreign

Economic Activity, published by the decision on behalf of the Council of the Eurasian

Economic Commission dated July 16, 2012, No. 54.

In addition, the order specifies specific calendar dates from which the labelling of this type of product (product) becomes mandatory for all participants in the trade turnover in the Russian Federation.

Administrative responsibility has been established for late entry of data into the GIS MT, or the entry of false data into it (Federal Law No. 58-FZ).

\section{Preferential characteristics of goods labelling in the Russian Federation}

The goods marking and traceability system reduces the administrative and regulatory burden on bona fide participants in the goods turnover by collecting and storing the necessary information about the turnover of goods for the authorised bodies to carry out appropriate control measures.

On the other hand, the goods labelling and traceability system allows bona fide participants in the goods turnover to increase productivity, optimise logistics costs and business processes, increase their market share and increase their income, in particular, the following contributes to this: 
- increase in market share and revenue due to the withdrawal of unscrupulous manufacturers from the market. According to the HSE research (August 2020), by reducing the share of illegal trafficking, bona fide business entities will be able to increase market share and production by $5-50 \%$. The cost price will decrease, and the retail price of products will be reduced by $5-10 \%$;

- in logistics, conditions will be created for savings in building logistics (at least 20\%), as well as errors related to the human factor in the preparation of accompanying documents will be reduced up to $90-95 \%$;

- control of price changes of labelled goods at all stages of its life cycle, a tool for identifying links in the commodity chain in which high margins arise, and timely response of control and supervisory authorities to take appropriate measures.

Thus, according to the study results conducted by the Federal Antimonopoly Service of Russia (Letter of the FAS of Russia N RP/85112/18), the introduction of labelling will not have a tangible impact on the goods price subjecting to labelling, which will be significantly lower than the average annual inflation rate.

In turn, the system will allow end-users to:

- check the legality and quality of the marked goods;

- realise non-governmental control using the Honest MARK mobile application;

- $\quad$ protect life and health by excluding illegal goods from circulation.

It should also note the advantages for the state from the introduction of labelling, in particular:

- understanding the market and control of the turnover of finished products in the country (in real-time);

- excluding expenses of the Russian Federation budget system for the introduction and development of a system of labelling and traceability of goods;

- stimulating the "whitewashing" of commodity markets;

- ensuring the legal turnover of products;

- ensuring the traceability of a specific unit of goods;

- increasing the collection of customs and tax, including excise payments;

- saving budget costs for the control of commodity markets;

- $\quad$ statistics on a country-wide scale in real-time;

- improving the efficiency of control and supervisory activities, including through automation of control and supervisory procedures;

- improving the effectiveness of public control through the use of the application "Honest Know";

- the ability to identify the dominant position of market participants and the suppression of cartel collusion;

- the possibility of obtaining analytical and statistical reports on various product groups from the labelling and traceability system;

- identification of the level of mark-up on goods at all stages of the supply chain; 
- collusion detection in public procurement by comparing purchase prices with current market prices;

- $\quad$ promotion of quality control of products sold, prevention of actions misleading consumers;

- the possibility of unambiguous identification of goods illegally in circulation, its belonging to a specific batch of products and the production site of an unscrupulous participant in the goods turnover;

- the possibility of "blocking" the goods movement in the supply chain in the event of an incident or detection of a violation to this product;

- $\quad$ getting access to the register of permits for goods through the functionality of the goods marking and traceability system;

- the possibility of integration with other state information systems of federal executive authorities and obtaining the necessary information from them.

\section{Discussion}

Despite the well-established and digitized labelling system of goods on the territory of the Russian Federation and its compatibility with labelling control systems in other countries, there are still some elements of the system that allow bypassing it, although this fact is becoming increasingly rare.

In this regard, it seems necessary to further study the features of the Concept of Creating and Functioning of Labelling Goods System Using Identification and Traceability of the Goods Movement in the Russian Federation to debug it and prevent violations and counterfeiting, as well as minimize the variations of the system circumvention.

The authors propose to expand the groups of goods for which legally significant terms of mandatory labelling using identification and obligations to enter information about all stages of the commodity distribution chain in GIS MT and FGIS MDLP are valid.

\section{Conclusion}

Traceability as an element of the system of state control over the turnover of goods is extremely significant for the management of commodity flows, tax deductions and product quality. Goods labelling makes it possible to solve not only economic issues of the state but also social ones. Due to mandatory labelling, counterfeit manufacturers are leaving the market. It becomes easier for legal companies to compete with each other. Sellers avoid fines for selling low-quality products and refunds from dissatisfied consumers. Business revenues are growing.

The state needs to control the functioning of the market and fight the shadow sector. The mandatory labelling system allows the state to control the turnover of goods and prevent fakes and counterfeit goods from entering the market. As a result, the budget receives more taxes, since the number of companies that operate illegally is decreasing. 


\section{References:}

Agreement on the Goods Marking Using an Identification in the Eurasian Economic Union dated February 2, 2018. (in Russian)

Agreement on Goods Marking Using an Identification in the Eurasian Economic Union dated February 2, 2018. (in Russian)

Decree of the President of the Russian Federation No. 683 "On the National Security Strategy of the Russian Federation" dated December 31, 2015. (in Russian)

Decree of the Government of the Russian Federation No. 836 "On Conducting an Experiment on Labelling Using an Identification of Certain Types of Dairy Products on the Territory of the Russian Federation" dated June 29, 2019. (in Russian)

Decree of the Government of the Russian Federation No. 1028 "On Conducting an Experiment in the Territory of the Russian Federation on Marking Wheelchair Identification Devices Related to Medical Devices and Monitoring Their Turnover" dated August 7, 2019. (in Russian)

Decree of the Government of the Russian Federation No. 1183 "On Conducting an Experiment on Marking Bicycles and Bicycle Frames Using an Identification and Monitoring the Turnover of These Products" dated September 11, 2019. (in Russian)

Decree of the Government of the Russian Federation No. 348 "On Conducting an Experiment on Labelling Using an Identification of Packaged Water on the Territory of the Russian Federation" dated March 27, 2020. (in Russian)

Federal Law No. 58-FZ "On Amendments to the Code of Administrative Offences of the Russian Federation" dated April 15, 2019. (in Russian)

Federal Law No. 61-FZ “On Circulation of medicines” dated April 12, 2010. (in Russian)

Federal Law No. 381-FZ "On the Fundamentals of State Regulation of Trade Activities in the Russian Federation” dated December 28, 2009. (in Russian)

Letter of the FAS of Russia N RP/85112/18 dated October 22, 2018. (in Russian)

National Marking System "Honest MARK". Official website of the national digital marking system "Honest MARK". Retrieved November 10, 2021 form https://xn-80ajghhoc2aj1c8b.xn--p1ai/o-chestnom-znake/nacionalnaya-sistema-markirovki/_ (in Russian)

Order of the Government of the Russian Federation No. 2963-r "On Approval of the Concept of Creation and Functioning of a System for Marking Goods Using an Identification and Traceability of the Goods movement in the Russian Federation” dated December 28, 2018. (in Russian)

Order of the Government of the Russian Federation No. 792-r "On Approval of the List of Individual Goods Subjecting to Mandatory Labelling Using an Identification" dated April 28, 2018. (in Russian)

Order of the Government of the Russian Federation No. 899-r "On Approval of the Essential Terms of the Public-Private Partnership Agreement Concluded for the Purpose of Creating, Operating, and Maintaining an Object Designed to Ensure the Marking and Traceability of Certain Types of Goods" dated May 8, 2019. (in Russian) 
Order of the Government of the Russian Federation No. 620-r "On the Operator of the State Information System for Monitoring the Goods Turnover of Subject to Mandatory Labelling Using an Identification" dated April 3, 2019. (in Russian)

Order of the Government of the Russian Federation No. 2828-r "On the determination of

Operator-CRPT LLC as Authorized to Perform the Functions of an Operator of a System for Monitoring the Medicines Movement for Medical Usage” dated December 18, 2018. (in Russian)

Order of the Government of the Russian Federation No. 2592-r "On the Strategy for Combating Illegal Trafficking of Industrial Products in the Russian Federation for the Period up to 2020 and the Planning Period up to 2025" dated December 5, 2016. (in Russian) Shklyaruk M.S. (Ed.) (2019). The state as a platform: People and Technologies. Moscow: Russian Academy of National Economy and Public Administration. (in Russian)

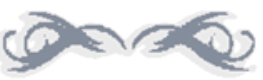

\section{Appendix}

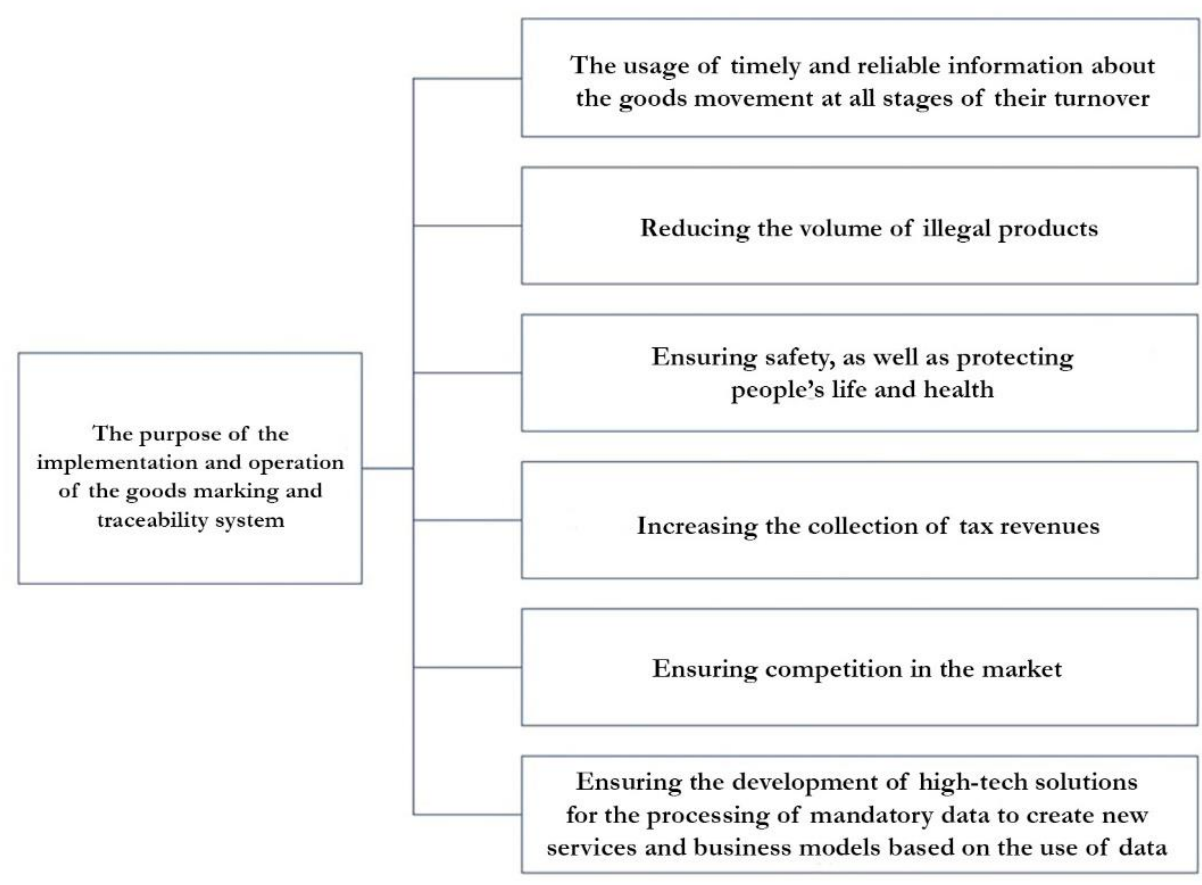

Figure 1. Purposes of the implementation of the goods marking and traceability system (Order of the Government of the Russian Federation No. 2963-r) 


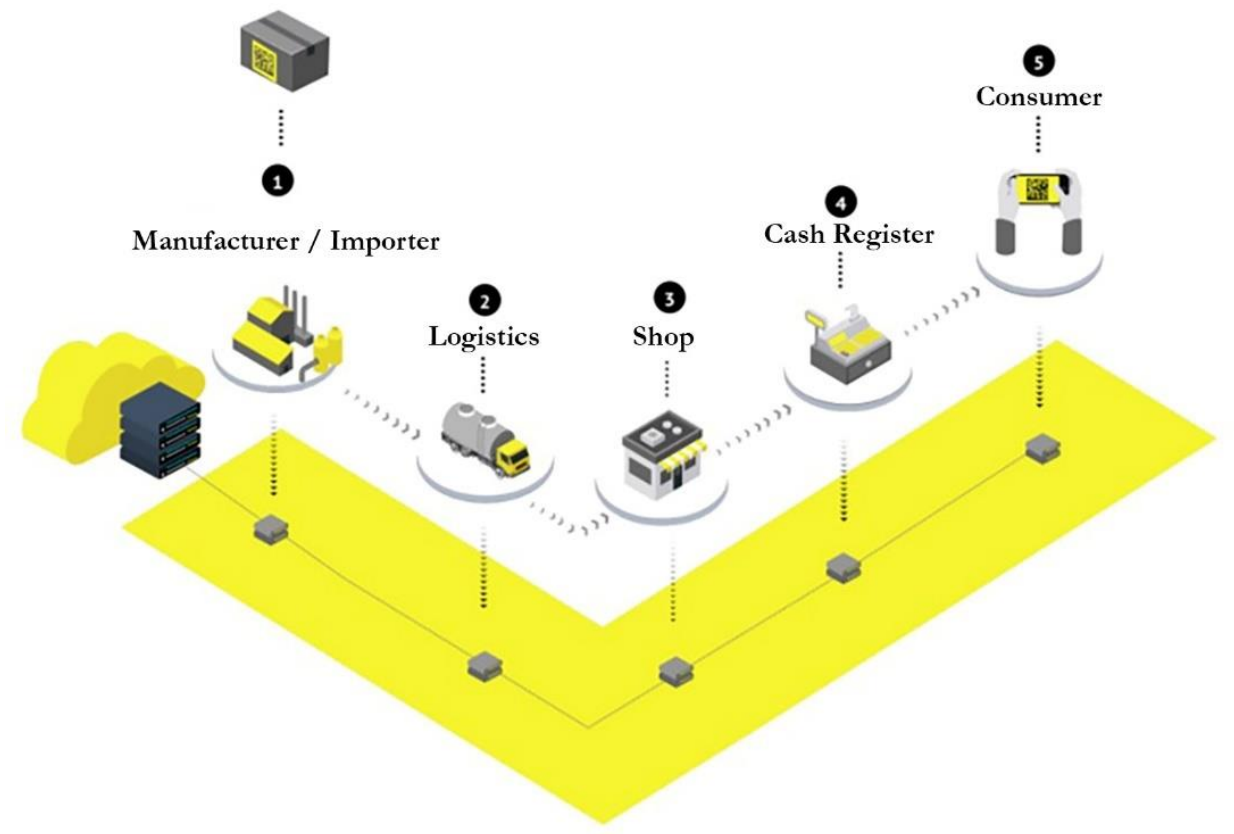

Figure 2. Stages of product turnover using the digital marking and traceability system (National Marking System "Honest MARK")

\begin{tabular}{|l|}
\hline \multicolumn{1}{|c|}{ Marking } \\
\hline Dairy products \\
Medicines \\
Tobacco \\
Light industry goods \\
Footwear \\
Fur coats \\
Perfume and eau de toilette \\
Tires and tires \\
Cameras and flash lamps \\
\end{tabular}

\begin{tabular}{|l|}
\hline \multicolumn{1}{|c|}{ Experiment } \\
\hline Packed water \\
Dietary supplements \\
Beer and beer drinks \\
Bicycles \\
Wheelchairs \\
\\
\end{tabular}

Figure 3. Commodity groups subjecting to mandatory labeling, and in respect of which a labelling experiment is being conducted (Order of the Government of the Russian Federation No. 792 r, Decree of the Government of the Russian Federation No. 836; Decree of the Government of the Russian

Federation No. 1028; Decree of the Government of the Russian Federation No. 1183; Decree of the Government of the Russian Federation No. 348) 